\title{
AGRONOMIC PERFORMANCE OF SINGLE CROSS MAIZE (ZEA MAYS L.) HYBRIDS UNDER ZONE 3 OF KARNATAKA
}

\author{
N. SHASHIDHARA ${ }^{1 *}$ \& JITENDRAKUMAR S HILLI ${ }^{2}$ \\ ${ }^{1}$ Assistant Professor, Department of Genetics and Plant Breeding, UAS, Dharwad \\ ${ }^{2}$ Special Officer (Seeds), Seed Unit, University of Agricultural Sciences, Dharwad
}

\begin{abstract}
APSTRACT
Hybridization plays a vital role in increasing the production and productivity of maize. Evaluating maize hybrids in a specific environment is a key task for the hybrid maize program. The objective of this study was to identify a promising maize hybrid for zone 3 of Karnataka. eight maize hybrids were evaluated including checks in a randomized complete block design (RCBD) with three replications during the Kharif season of 2020 -21 at the Agricultural Research Station, Arabhavi field of University of Agricultural Sciences, Dharwad. The results suggested that among tested hybrids, PAC 745 Gold (12.021 tons ha ${ }^{-1}$ ) of UPL Limited (Advanta Limited), Hyderbad, followed by MRM 4070 (11.514 tons ha ${ }^{-1}$ ) of Mahyco Co. Jaina compared with the National Check, NK - $6240\left(11.270\right.$ tons ha $\left.{ }^{-1}\right)$ and private check CP - $818(11.055$ tons $\mathrm{ha}^{-1}$ ). Hence the study suggested PAC 745 Gold of UPL Limited (Advanta Limited), Hyderbad and MRM 4070 of Mahyco Co. Jaina as promising hybrids for the maize growers in the zone 3 of Karnataka.
\end{abstract}

KEYWORDS: Performance, Maize hybrids, Evaluation, hybrids, Zone 3

Received: Dec 04, 2020; Accepted: Dec 24, 2020; Published: Dec 31, 2020; Paper Id: IJASRDEC202019

\section{INTRODUCTION}

Maize is called as queen of cereal due to its great importance in human, animal diet and high yielding ability. It efficiently utilizes solar energy and has immense potential for higher yield, and called as "Miracle Crop". It is the crop of the future as mentioned by the Father of Green Revolution, Renounced Nobel Laureate Dr. Norman E. Borlaug. Maize plays a vital role in ensuring food security as well as nutritional security through quality protein (Rawool, 2004). In India, area and production of maize are about 9.23 million hectares and 23.73 million tonnes respectively, having average productivity about $2564 \mathrm{~kg}$ ha-1. In Maharashtra, the area and production of maize is about 1.35 million hectares and 4.40 million tonnes production with the productivity of $3500 \mathrm{~kg}$ ha-1 (Anonymous, 2015). It ranked next to rice, wheat and sorghum in respect of area and production. Though it is consumed all over the country but it is a staple food of people in hilly and sub mountain area of North India. It is extensively grown in Uttar Pradesh, Karnataka, Maharashtra, Bihar, Rajasthan, Madhya Pradesh etc. (Dayanand and Jain, 1994). Climate variability has a direct influence on the quantity and quality of maize production as water shortage combined with thermal stress adversely affect maize productivity. To deal with the impact of climate change, the potential adaption strategies are changing sowing dates; crop diversification, integrated farming system, etc. Optimum sowing date is important to mitigate climate change. Growing a suitable hybrid at an optimum sowing time may be better agronomic option under the zone 3 of Karnataka. Further, there is need to evaluate the different maturity hybrids of maize for their growth and yield under varying sowing dates (Parashar, 2011). 


\section{MATERIALS AND METHODS}

The hybrids under evaluation were sown in Randomized complete block design with three replications with spacing of 60 $\mathrm{cm}$ between the rows and $20 \mathrm{~cm}$ between the plants. Each entry was raised in four rows of 4 meter length by dibbling two seeds per hill and later thinned down to single seedling after 15-18 days after sowing. The standard recommended package of practices was followed to raise a healthy and disease free crop.

At pre-flowering stage initial plant count was recorded from entire four rows and in all three replications, followed by days to $50 \%$ pollen shedding and days to $50 \%$ silking was recorded. Later five randomly chosen plants were selected for recording plant height $(\mathrm{cm})$ and ear height traits $(\mathrm{cm})$. Cob weight per plot, cob number and moisture $(\%)$ were recorded at the time of harvest of the crop. Furthermore, ten cobs were randomly selected, shelled and grain weight and pith weight was documented. Shelling per cent was calculated using the grain weight and pith weight of these ten sampled cobs. Cob weight per plot, moisture (\%) and shelling (\%) was used to calculate grain yield and expressed at 15 per cent moisture. The grain yield was computed using the below mentioned formula.

Grain yield (tons $)=\{[$ Cob weight $(100-\%$ grain moisture $)$ Shelling per cent $x 10000]-$ (100 x Per cent grain moisture $x$ plot area) $\} / 1000$

\section{Statistical Analysis}

The obtained field data were subject statistical analysis compute all the critical difference and the variance (Sunderraj et al., 1972).

\section{EXPERIMENTAL RESULTS AND DISCUSSION}

Among the hybrids tested for their yield performance, the hybrid from UPL Limited (Advanta Limited), Hyderabad PAC 745 Gold recorded highest in all the yield attributing characters like ear height $(58.00 \mathrm{~cm})$, cob weight $(11.16 \mathrm{~kg})$ and shelling percentage $(83.36 \%)$ with highest recording yield of 12.021 tonnes per hector which was followed by the hybrid MRM 4070 from Mahyco Co. Jaina ear height $(49.33 \mathrm{~cm})$, cob weight $(9.16 \mathrm{~kg})$ and shelling percentage $(82.62 \%)$ with the yield of 11.514 tonnes per hector. These results indicates that the, among the tested entries at the Agricultural Research Station, Arabhavi, PAC 745 Gold from UPL Limited (Advanta Limited), Hyderabad was showed significantly higher yield compared with other entries. Hence, the experiment showed that the, above hybrid is suitable for the zone 3 of Karnataka.

The results indicate that the test hybrid PAC 745 Gold from UPL Limited (Advanta Limited), Hyderabad was the highest yielding maize hybrid with $12.02 \mathrm{t} / \mathrm{ha}$ grain yield (Table 1) and it was numerically superior over National check hybrid NK-6240 by 13.8 per cent and over popular private hybrid check CP-818 by 11.7 per cent. It was followed by MRM 4070 (11.54 t/ha) and S-505 (10.05 t/ha). The obtained results are in line with Jadhav et al., 2015; Hemalatha et al., 2013 and Sulochana et al., 2015.

The ancillary data of the test hybrids in comparison with the check hybrids (Table 2) indicated that, the test hybrids were on par for days to $50 \%$ flowering and days to $50 \%$ silking with the check entries. The yield contributing traits $\mathrm{Cob}$ length, No of Kernel rows and No of Kernels/ row in the test hybrid PAC 745 Gold recorded were significantly superior over National check NK-6240 


\section{CONCLUSIONS}

Among the four test hybrids from UPL Limited (Advanta Limited), Hyderabad the test hybrid PAC 745 Gold recorded highest grain yield of $12.021 \mathrm{t} / \mathrm{ha}$ and it was superior over the National Check (NK-6240) by 13.8 per cent and also over popular private hybrid (CP-818) by 11.7 per cent. This was followed by another test hybrid MRM 4070 and S-505 which recorded $11.514 \mathrm{q} / \mathrm{ha}$ and 10.05 t/ha grain yield respectively.

\section{REFERENCES}

1. Anonymous, 2015. The current status published on website - http: //www.indiastat.in.

2. Dayanand and Jain, O. P. 1994. Rabi maize cultivation for enhanced production. India Fm., 43 (10): 11-12.

3. Hemalatha, S., Sreelatha D., Anuradha, M. and Saikumar, R. 2013. Crop weather relations in maize. J. Agrometeorlogy, Andhra Pradesh, 15(92):165-166.

4. Jadhav, A., Kumar A., Singh, A. K., Singh, I. and Das, T. K. 2015. Response of maize hybrids (Zea mays L.) to staggered sowing. Indian Journal of Agronomy., 60(3):476-478.

5. Parashar, A. 2011. Phenology and productivity of maize cultivars as influenced by crop weather environment. M.Sc. Thesis, Maharana Pratap University of Agriculture and Technology, Udaipur.

6. Rawool, H. V. 2004. Effect of integrated nutrient management on yield and nutrient balance in maize (Zea mays L.). Indian J. Agril. Sci., 46(4): 698-701.

7. Sulochana, Solanki, N. S., Dhewa, J. S. and Bajia, R. 2015. Effect of sowing dates on growth, phenology and agro meterological indices for maize varieties. An International Quarterly Journal of Life Sciences. 10(3): 1339- 1343.

8. Sunder raj, N., Nagaraju, S., Venkararamu, M. N. and Jagannath, M. K., 1972.Designs and analysis of field Experiment, Univ. Agril.Sci., Hebbal, Bangalore.

Table: 1: Grain Yield of the Test Hybrids and Per Cent Superiority over the Check Hybrids

\begin{tabular}{|c|l|l|c|}
\hline SI.No. & Source of hybrids & Entry & Grain yield (t/ha) \\
\hline 1 & Mahyco Co. Jaina & MRM 4070 & 11.514 \\
\hline 2 & Mahyco Co. Jaina & MRM 4065 & 7.798 \\
\hline 3 & Spriha BioSciences Pvt. Ltd., Hyderabad & S-505 & 10.273 \\
\hline 4 & UPL Limited (Advanta Limited) Hyderbad & PAC 740 & 9.850 \\
\hline 5 & UPL Limited (Advanta Limited) Hyderbad & PAC 745 Gold & 12.021 \\
\hline & \multicolumn{2}{|c|}{ Checks } \\
\hline 6 & Local Check (LC) & GH-0727 & 7.186 \\
\hline 7 & National check (NC) & NK-6240 & 11.270 \\
\hline 8 & Private Check (Pvt.C) & CP-818 & 11.055 \\
\hline & S. Em + & \multicolumn{2}{l|}{} \\
\hline & CD @ (5.0\%) & & 7.61 \\
\hline & CV $\%$ & 17.33 \\
\hline
\end{tabular}


Table 2: Mean Ancillary data of the test Hybrids in comparison with checks

\begin{tabular}{|c|c|c|c|c|c|c|c|c|c|}
\hline Genotypes & $\begin{array}{l}\text { Days to } 50 \% \\
\text { Pollen Shed }\end{array}$ & $\begin{array}{c}\text { Days to } \\
50 \% \text { Silk }\end{array}$ & $\begin{array}{c}\text { Plant } \\
\text { Height (cm) }\end{array}$ & $\begin{array}{c}\text { Ear Height } \\
(\mathrm{cm})\end{array}$ & $\begin{array}{c}\text { Cob weight per } \\
\text { plot (kg) }\end{array}$ & $\begin{array}{c}\text { Grain } \\
\text { Moisture } \%\end{array}$ & $\begin{array}{c}\text { Shelling } \\
\%\end{array}$ & $\begin{array}{c}100 \\
\text { Grain weight }\end{array}$ & $\begin{array}{c}\text { Grain Yield } \\
\text { tons /ha }\end{array}$ \\
\hline MRM 4070 & 59.33 & 65.00 & 132.0 & 49.33 & 9.16 & 18.53 & 82.62 & 37.12 & 11.514 \\
\hline MRM 4065 & 65.00 & 68.66 & 103.0 & 49.33 & 8.5 & 21.93 & 79.53 & 32.76 & 7.798 \\
\hline S- 505 & 64.00 & 66.66 & 112.66 & 53.00 & 8.5 & 16.53 & 83.71 & 34.18 & 10.055 \\
\hline PAC 740 & 67.33 & 71.00 & 120.66 & 54.66 & 9.0 & 18.53 & 86.72 & 28.39 & 9.850 \\
\hline $\begin{array}{l}\text { PAC } 745 \\
\text { Gold }\end{array}$ & 67.66 & 69.66 & 130.00 & 58.00 & 11.16 & 17.76 & 83.36 & 38.91 & 12.021 \\
\hline \multicolumn{10}{|l|}{ Checks } \\
\hline $\begin{array}{l}\text { GH-0727 } \\
\text { (LC) }\end{array}$ & 63.33 & 66.66 & 125.66 & 57.66 & 6.83 & 18.96 & 85.82 & 36.56 & 7.186 \\
\hline $\begin{array}{l}\text { NK-6240 } \\
\text { (NC) }\end{array}$ & 60.33 & 65.00 & 110.66 & 50.33 & 10.66 & 19.16 & 86.74 & 38.31 & 11.270 \\
\hline $\begin{array}{l}\text { CP-818 } \\
\text { (Pvt.C) }\end{array}$ & 59.00 & 65.66 & 118.66 & 53.33 & 8.83 & 18.76 & 86.17 & 36.83 .3 & 11.055 \\
\hline $\mathrm{S} . \mathrm{Em} \pm$ & 1.33 & 1.19 & 3.9 & 2.9 & 1.65 & 1.92 & 5.05 & 0.72 & 1.63 \\
\hline $\begin{array}{l}C D @ \\
(5.0 \%)\end{array}$ & NS & NS & 11.8 & 8.7 & NS & NS & 3.18 & NS & 7.61 \\
\hline $\mathrm{CV} \%$ & 3.82 & 3.38 & 3.5 & 4.8 & 14.61 & 5.86 & 15.95 & 2.58 & 17.33 \\
\hline
\end{tabular}

